\title{
12.1
}

\section{A Paleogeographic Model for Vendian and Cambrian Time}

\author{
JOSEPH L. KIRSCHVINK
}

\subsubsection{Introduction}

In any attempt to construct a set of paleogeographic reconstructions, it is necessary to make sense out of a variety of sometimes conflicting sets of geological, paleontological, and geophysical constraints. Because the applicability of biostratigraphic correlation diminishes with increasing geologic age (Chapter 10), it is necessary that reconstructions of Late Proterozoic paleogeography (as well as those of the earliest Paleozoic) be anchored well within the Paleozoic, and only then be extended as far as feasible into the Precambrian. However, few reconstructions of Cambrian paleogeography have reconciled in a satisfactory manner both the pronounced lithologic and faunal variations that are known to occur with the often sparse paleomagnetic constraints (Jell 1974; Shergold 1988; Courjault-Radé 1987; 1988). Thus, it is necessary first to produce consistent tectonic and paleontological models for Cambrian time before attempting an extension into the Precambrian.

Temporal correlation is the most severe problem encountered in dealing with the Proterozoic time. Paleomagnetic data from rocks of this age are of highly variable quality, and are plagued with large uncertainties in the age of various components. After careful examination of the existing paleomagnetic data, we have chosen to limit our attempts at a detailed reconstruction to the Vendian, from the approximate time of the last glacial episode of the Neo-Proterozoic Cryogenian System (see Table 1.1.1) through to the Cambrian-Ordovician boundary. Several factors influence this decision, including the low number of well dated or stratigraphically constrained paleomagnetic determinations for Early and Middle Proterozoic time, and the general lack of intercontinental correlation between them. Precambrian paleomagnetic data have been used to support a wide variety of conflicting models of Precambrian plate motions, both for and against the existence of modern-style plate tectonics and even for an expanding earth (Piper 1982, 1983, 1986; Schmidt and Embleton 1981; Klootwijk 1980). In a recent review of the African Proterozoic paleomagnetic data, for example, Perrin et al. (1988) concluded that directional scatter in the published directions was so high, and the age constraints so lax, that any number of distinctly different apparent polar wander paths (APW paths) could be drawn through them.

Nevertheless, paleomagnetic data from Early and Middle Proterozoic time do seem to have an angular and temporal coherence that is difficult to explain without the presence of some sort of large supercontinent (Piper 1983, 1986; Schmidt and Embleton 1981). Furthermore, recent studies of thermal subsidence histories support the hypothesis that one or more large continental masses broke up shortly before the Precambrian-Cambrian boundary (Armin and Mayer 1983; Bond and Kominz 1984; Bond et al. 1984), with intermittent episodes of rifting which began somewhat earlier. These are appealing hypotheses because, if true, the presence of one or more amalgamations of continental masses would greatly simplify the problem of reconstructing their positions. However, our analysis of climatic and biostratigraphically constrained paleomagnetic information for Vendian and Cambrian time suggests that East and West Gondwana were separate and presumably did not join until Early or Middle Cambrian time, which is roughly coincident with the end of the pan-African metamorphic event along the eastern margin of Africa (Kröner 1980; Dixon and Golombek 1988). At the minimum, therefore, there were probably at least two large supercontinents in the Late Proterozoic.

In selecting the paleomagnetic poles used as constraints for our reconstructions for the Vendian and Cambrian, we have used almost exclusively data from paleontologically or stratigraphically constrained, unmetamorphosed sedimentary sequences, with virtually all such data derived from samples treated with progressive thermal demagnetization. Although such rocks are sometimes plagued by problems produced by secondary chemical overprints, their superior age control, relatively accurately determined paleo-horizontal orientation, and the numerous opportunities they provide for field tests (e.g., fold, reversal, conglomerate, etc.) to determine the age of the remanence, mark them as the best available for this purpose. We apologize to those readers whose preferred poles are not used here; however, we found that no coherent scheme is possible that incorporates all published results. Detailed discussions of the data used are given below for the four major 
reference continents (Australia, Siberia, North America, and Africa).

Finally, it also helps to use an additional assumption that extensive deposits of platform-type carbonates were deposited within an equatorial carbonate belt similar in character to that which has existed in post-Paleozoic time. Ziegler et al. (1984) argue that the major factor constraining the Cenozoic carbonate platforms to lie within about $33^{\circ}$ of the equator is the need for carbonate-precipitating algae to have at least some direct sunlight each day; nearly total reflection of sunlight at the ocean surface will shut off light during the winter at higher latitudes, limiting algal growth. This model is compatible with a large body of Cambrian paleomagnetic data, and helps position plates (such as the Baltic Platform) for which there is as yet inadequate paleomagnetic control.

In our attempts to reconcile our reconstructions for Late Proterozoic and Cambrian time with those of other workers (e.g., Ziegler et al. 1979; Scotese 1984; Van der Voo 1988), we encountered a problem in the placement of the Siberian and Baltic Platforms relative to North America (Ripperdan and Kirschvink 1989a,b). The most parsimonious reconstruction that we could find to reunite Early Cambrian faunal provinces was to put these blocks to the west of North America, whereas in the most popular reconstructions for later Paleozoic times they are positioned off the eastern margin, closer to their present positions. Hence, our model implies oblique, left-lateral subduction during the post-Cambrian closure of the Iapetus Ocean between Baltica and the Appalachian margin of North America, and right-lateral motion of some sort between Siberia and the Cordilleran margin. Although other interpretations for the faunal distributions are certainly possible within the frame- work of the more conventional schemes, we felt this in particular might serve to stimulate discussion of the alternatives.

The following Sections will first provide an overview of our selection of paleomagnetic data used to partially constrain the orientation of the major continents, followed by a discussion concerning how smaller or less well-constrained fragments have been fit to these major fragments. The final discussion will concern the lithologic and faunal constraints.

\subsubsection{Paleomagnetic Data}

Of the four major continents (Australia, Siberia, North America, and Africa) that have more than one stratigraphically constrained paleomagnetic result for Vendian and Cambrian time, Australia and North America have the most and perhaps best data. Results for the Baltic Platform in this time interval are rather sparse (Pesonen et al. 1989), and many from Siberia are difficult to interpret. A summary of the data for each of these cratons follows below, and will focus primarily on results on two major time slices at the basal Vendian glaciation and the Precambrian-Cambrian boundary (taken as the time equivalent of the base of the Tommotian Stage of the Siberian Platform: Rozanov 1984; Cowie 1985). Compilations of paleontologically dated Cambrian data will be provided where needed for brevity. Figures 12.1 through 12.4 show our selected apparent polar wander (APW) paths for each of these cratons.

\subsubsection{A Australia}

Australia has the best positional constraint for the basal Vendian glacial epoch of any continent, based on the paleomagnetic study of the Elatina Formation reported by Embleton and Williams (1986). The Elatina Formation con-

\section{Australian Vendian-Cambrian APW Path}

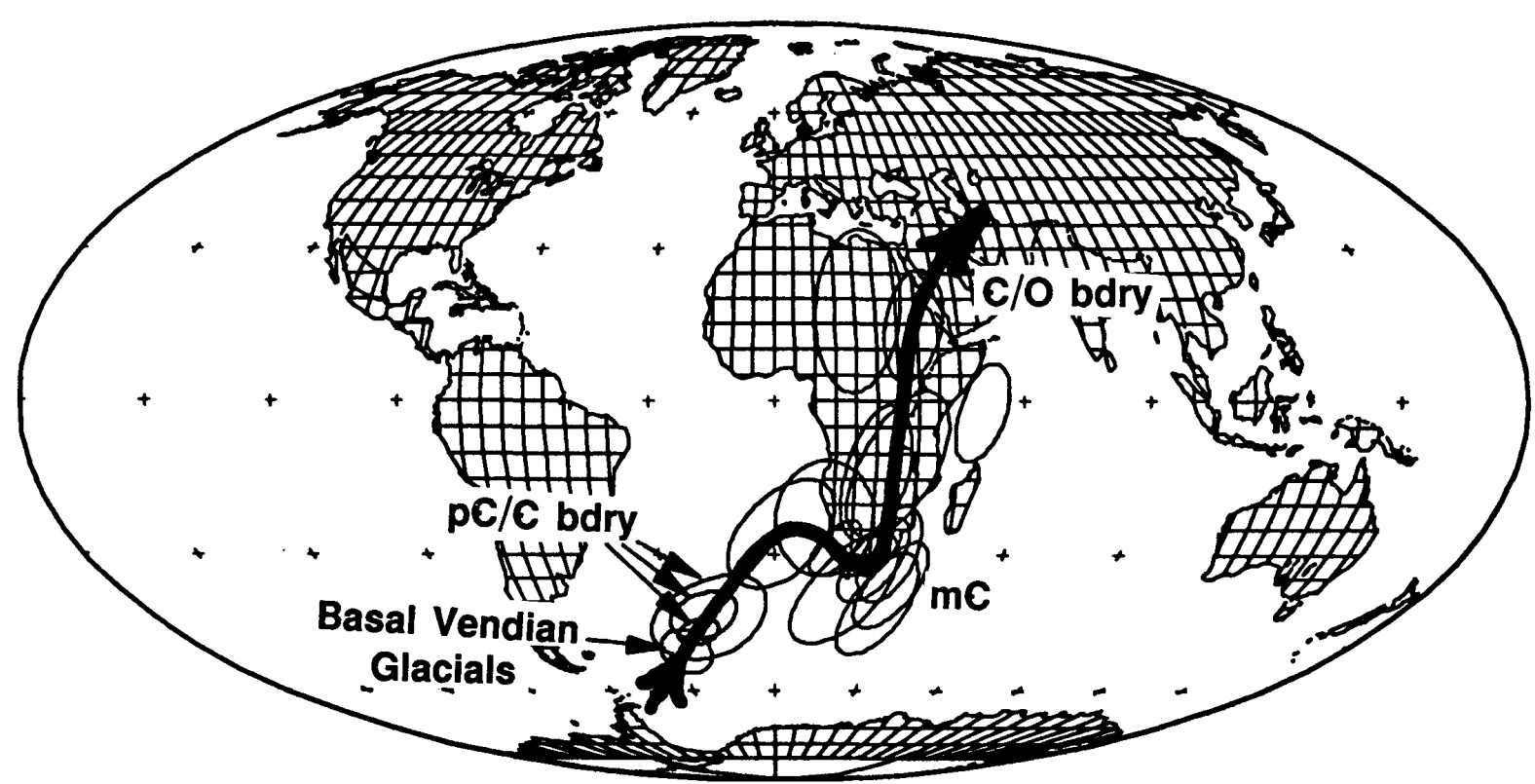

Figure 12.1 Vendian and Cambrian aparent polar wander (APW) path for Australia. The basal Vendian glacial pole is that from Embleton and Williams (1986), the Precambrian-Cambrian Boundary from Kirschvink (1978b), and the others from Klootwijk (1980). 


\section{Siberian Platform Vendian-Cambrian APW Path}

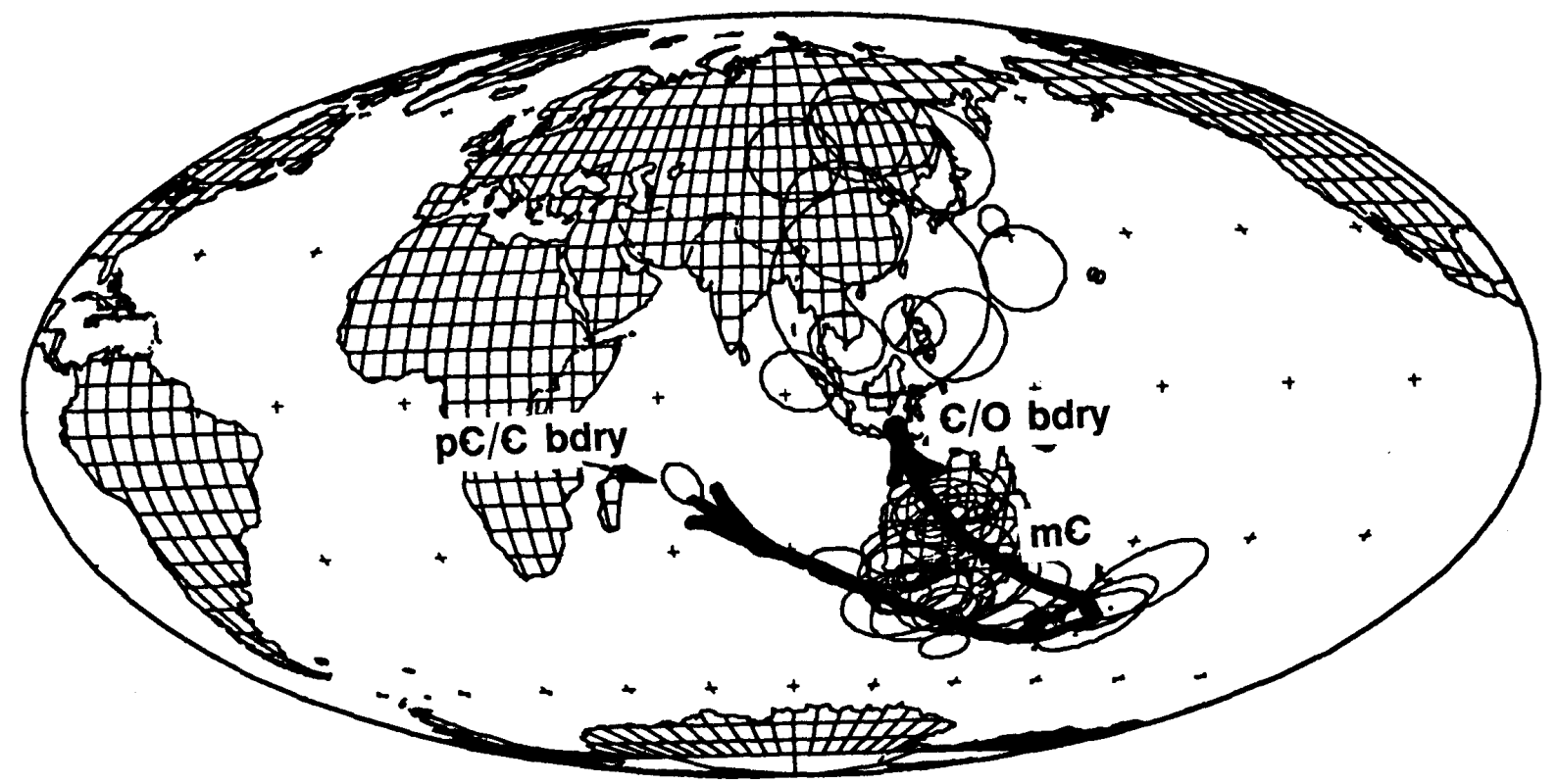

Figure 12.2. Vendian and Cambrian APW path for Siberia. The Precambrian-Cambrian pole is from Kirschvink and Rozanov (1984), and the others are taken from the Soviet compilations of Khramov (1982). Note that we have no good constraint for the Vendian of Siberia.

tains a series of rhythmic varves that formed on the outwash plain of the Marinoan glaciation, and is preserved in the Adelaide geosynclinal sequence of South Australia (Williams 1981). The magnetization in this unit is carried by detrital hematite with blocking temperatures in excess of $665^{\circ} \mathrm{C}$, whereas studies of subgraphitic kerogen in the area reveal that the rocks have not been subjected to temperature-time equivalents more than $160^{\circ} \mathrm{C}$ for $300 \mathrm{Ma}$, well below that necessary to remagnetize the hematite (Embleton and Williams 1986). A recent study on the Elatina by Summer et al. (1987 and in prep.) also yielded a positive fold test, supporting the interpretation that the magnetization was gained early in its depositional history. Both of these studies imply that these widespread glacial deposits of the basal Vendian (or Edicaran) Period of Australia were deposited within a few degrees of the equator. The profound climatic implications of this are discussed elsewhere in this volume (Section 2.3) and by Chumikov and Elston (1989), and provide the rationale used in our oldest reconstructions, where we assume this uppermost Cryogenian (basal Vendian) glaciation was a globally synchronous event.

As shown in Figure 12.1, the pole position obtained from the Elatina Formation is indistinguishable from three others obtained from middle to late Vendian and earliest Cambrian rocks of the Amadeus Basin sequence in central Australia (Kirschvink 1978a, b). These magnetizations passed the fold, unconformity, and reversal tests, and the magnetic polarity stratigraphy could be traced for a substantial distance along the northern margin of the Amadeus Basin of central Australia. Thus, the Australian continent experienced no detectable polar wander for the entire Vendian period, and the Eocambrian quasi-static interval (a period of no apparent polar wander), first detected by Kirschvink (1978a, b), probably includes the entire Vendian.

Klootwijk (1980) published a major monograph on the paleomagnetism of Australia covering the remainder of Cambrian time, providing a large number of key, biostratigraphically dated pole positions which can be used to constrain the relative motions of Gondwana. In general, these data imply that this continent rotated $90^{\circ}$ counter-clockwise $(\mathrm{CCW})$ around a Euler pole located in the vicinity of Tasmania during Cambrian time. The rotation, however, was not continuous. Roughly half of the motion occurred during the Early Cambrian, with relatively little during the Middle and the first half of the Late Cambrian. The remaining $45^{\circ}$ was confined entirely to the last half of the Late Cambrian (Klootwijk 1980). A new, magnetostratigraphically constrained pole position from the Cambrian-Ordovician boundary section at Black Mountain, Queensland, Australia (Ripperdan and Kirschvink, in prep.) confirms the earlier poles of this age as well as the magnitude of this rotation. Figure 12.1 shows the Vendian-Cambrian APW path for Australia.

\subsubsection{B Siberia}

A key constraint on the position of the Siberian Platform during the Tommotian Stage of the Early Cambrian is provided by Kirschvink and Rozanov (1984). In addition to recognizing a correlatable and consistent magnetic polarity stratigraphy, their paleomagnetic data demonstrated that a narrow, 1,500$\mathrm{km}$-long belt of archaeocyathid bioherms was stretched out precisely along the equator during Tommotian time. Apparently, the density and diversity of these early reef-forming organisms were sensitive to the slight climatic maxima centered 
on the equator as is, for example, the diversity of modern tropical land vertebrates in Africa. Although the position of the reef-like complex remains stable during the Tommotian, it shifts towards the NE portion of the platform in the early Atdabanian. Kirschvink and Rozanov (1984) interpret this shift as marking the time at which the Siberian Platform began to move off the equator, as well as reflecting the onset of the Cambrian sea-level transgression. Unfortunately, few reliable paleomagnetic data are available for the Vendian of Siberia, and the result of Kirschvink and Rozanov (1984) and data from the compilation of Khramov (1982) imply a rotation of nearly $90^{\circ}$ for Siberia during the Cambrian, as shown in Figure 12.2. The magnitude of this rotation, and the lack of reliable data within this period, introduce an ambiguity regarding how the APW path for Siberia should be connected between the Precambrian-Cambrian and Cambrian-Ordovician boundaries. This is complicated further by the use of a DC-demagnetization technique in much of the pre-1970 Soviet paleomagnetic data. However, it is clear from the extensive carbonates of this age that Siberia remained within the carbonate belt during both Vendian and Cambrian time, and faunal similarities in the Early and Middle Cambrian imply a close proximity to western Antarctica and Australia (Palmer and Gatehouse 1972). Thus, the most parsimonious position for Siberia is to fit its southeastern margin adjacent to the margins of western Antarctica and eastern Australia. In this orientation, the CCW rotation of Gondwana in the Early Cambrian will move Siberia northward (generating the proper relative motion for the archaeocyathid bioherms). Note that this orientation is opposite that used by Kirschvink and Rozanov (1984), and hence that their polarity interpretations should be switched.

\subsubsection{North America (Laurentia)}

Morris (1977) has conducted the most thorough paleomagnetic study of the uppermost Proterozoic glacial units yet done in North America. Using progressive alternating-field, thermal, and chemical demagnetization techniques on samples from the Rapitan Group of the Mackenzie Mountains of northwestern Canada, he discovered three magnetic components termed $X, Y$, and $Z$. Two of these (X and $Z$ ) imply a lowlatitude of formation, while the $\mathrm{Y}$ component implies high paleolatitudes. Using a micro-fold test on units deformed by a glacial dropstone, Sumner et al. (1987) discovered that this $Y$ component was a result of secondary chemical remagnetization, acquired sometime after emplacement of the dropstones. Hence, the $\mathrm{X}$ and $\mathrm{Z}$ components are the only possible primary directions, although there are no guarantees that either represents the original magnetization. For North America, however, there are several other paleomagnetic studies from radiometrically dated igneous bodies which yield similar poles (Fig. 12.3); hence, a position near the equator in the early Vendian is probable. Unfortunately, the Late Proterozoic glaciations are poorly dated and it is difficult to compare directions from the igneous bodies with those from the sedimentary record. For the purpose of these paleogeographic reconstructions, we have placed the Cordilleran margin of Laurentia adjacent to the northeastern margin of the Siberian Platform as suggested by Sears and Price (1978).

Between the time of the last Proterozoic glaciation and the early Middle Cambrian, there are very few stratigraphically constrained and reliable paleomagnetic directions for North America, particularly within the "Ediacaran" interval. Earlier results from the Late Proterozoic Desert Range, Nevada

\section{North American Vendian-Cambrian APW Path}

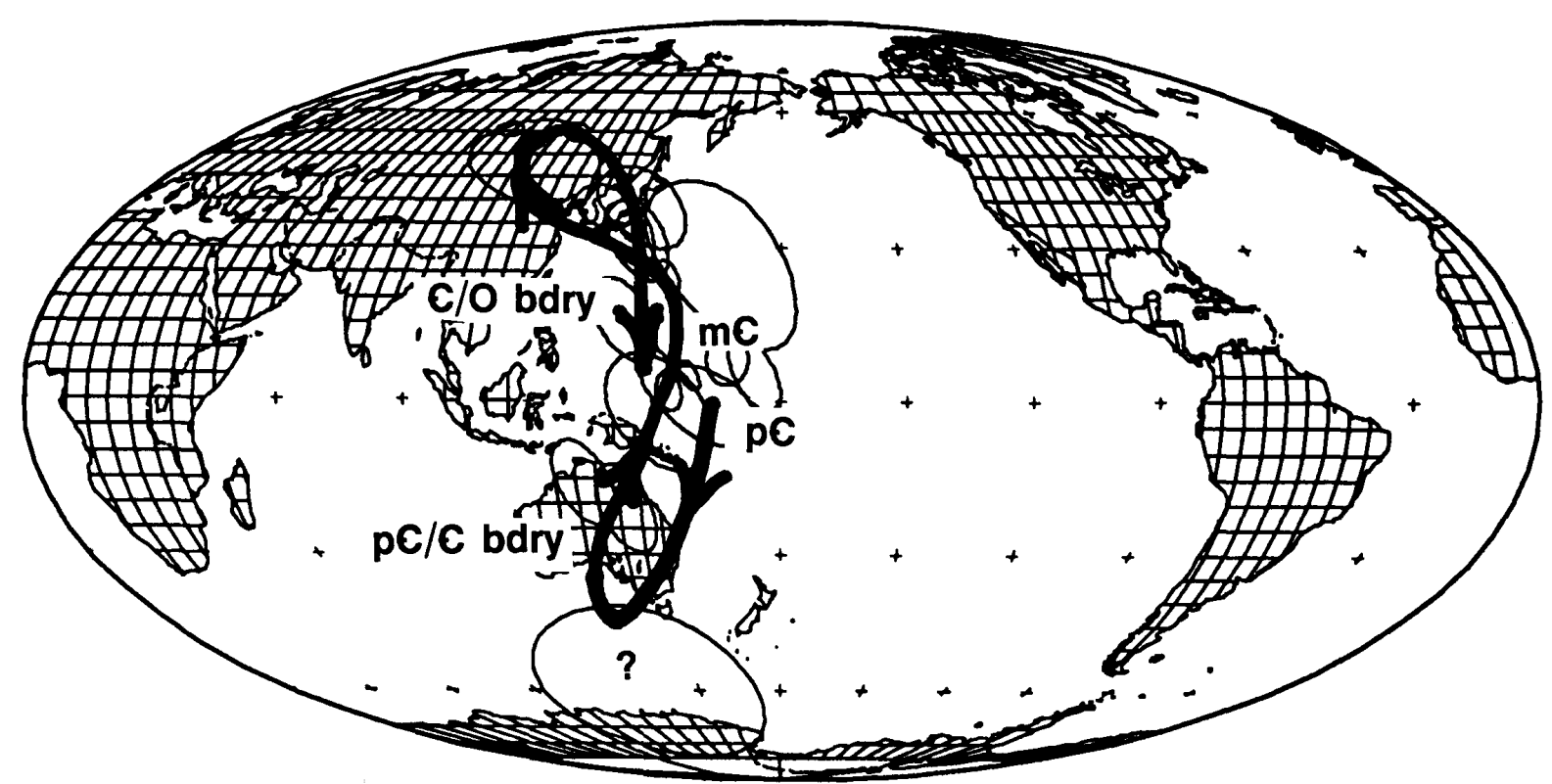

Figure 12.3. Vendian and Cambrian APW path for North America. Most of the poles are as used by Watts et al. (1980a,b), with the Tommotian result from Barr and Kirschvink (1983) which plots in Australia (both before and after correction for displacement on the SonoraMojave megashear). The querried direction is from Tanczyk et al. (1987), but is not biostratigraphically constrained in age. 


\section{African Vendian-Cambrian APW Path}

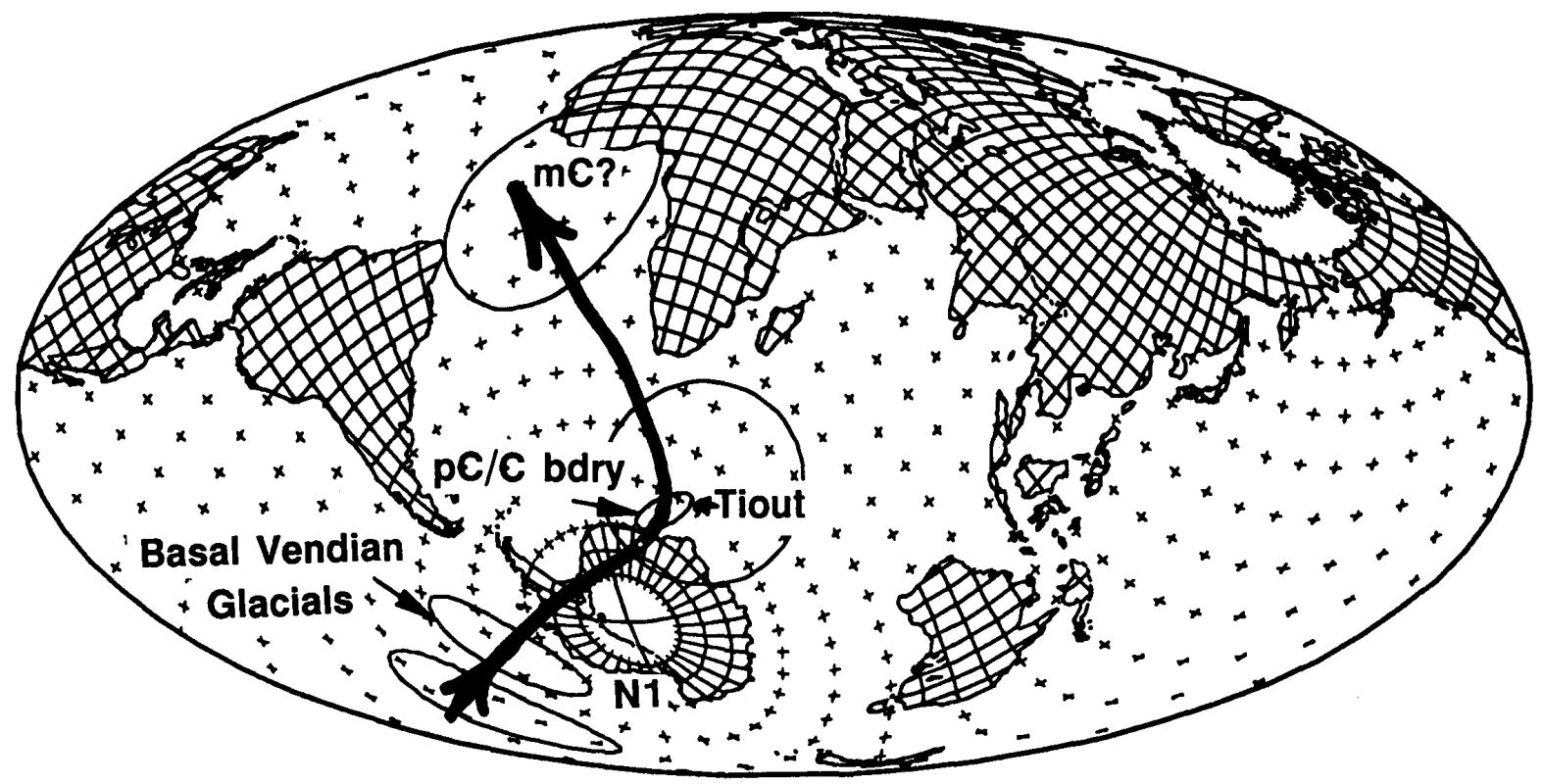

Figure 12.4. Vendian and Cambrian APW path for Africa. The basal Vendian galcial pole is the N1 direction of Kröner et al. 1980, and the mE? direction is their N3 overprint component. The Precambrian-Cambrian direction is that from Kirschvink (1980), supplemented with as yet unpublished data from additional samples from Morocco.

(Gillett and Van Alstine 1979; Van Alstine and Gillett 1979), were later found to be due to secondary magnetic components produced by thermal overprinting (Gillett and Van Alstine 1982), with the possible exception of a hematite-bearing unit of the (Ediacaran?) Rainstorm Member of the Johnnie Formation (from which we have recovered a few Ediacaran-like impressions in exposures at the Desert Range, Nevada). For the Tommotian, only one biostratigraphically constrained pole is available, from basaltic volcanics in the Puerto Blanco Formation near Caborca in northwestern Sonora, Mexico (Barr and Kirschvink 1983). McMenamin et al. (1983) described a fauna of small shelly fossils, similar in many respects to those of the Tommotian Stage in Siberia, from clastic units interbedded with the volcanics. The late Precambrian and early Paleozoic sequence at Caborca appears to be the lateral equivalent of the central Great Basin Sequence (Silver and Anderson 1974; Stewart et al. 1984) which has been displaced nearly $800 \mathrm{~km}$ in a left-lateral sense by the Sonora-Mojave megashear during Mesozoic time (Silver and Anderson 1974; Anderson and Schmidt 1983). The volcanics preserve a two-polarity characteristic component with a positive conglomerate test. Both before and after reconstruction for motion on the megashear (Anderson and Schmidt 1983), this paleomagnetic pole from Caborca is located in the vicinity of Australia as indicated on Figure 12.3. This implies that North America was in moderate southerly latitudes, with the Cordilleran margin to the north. A newly reported paleomagnetic pole, from intrusives dated at $540 \pm 22 \mathrm{Ma}(\mathrm{Rb} / \mathrm{Sr})$ from the Sept-Iles layered mafic intrusion in Quebec, Canada (Tanczyk et al. 1987), also falls in this vicinity (although the age of the magnetizations in this unit are not constrained biostratigraphically).

Paleomagnetic data of reasonable quality are again available for North America from the early Middle Cambrian through the Cambrian-Ordovician boundary (Watts et al. 1980a, b). By early Middle Cambrian time, North America was again at low latitudes as it was in the late Precambrian. This similarity in position between Late Proterozoic and Middle Cambrian time makes it tempting to ignore otherwise anomalous paleomagnetic results, and to assume simply that the continent remained stably on the equator during Vendian time. However, within the Early Cambrian there is some biostratigraphic and lithostratigraphic evidence which supports this northward migration. Lithologically, the Cordilleran appears to have on the margin an equatorial carbonate belt, whereas the Appalachian margin does not. For example, the first archaeocyathids which appear in carbonates on the Cordilleran margin are biostratigraphically older than those which are first found in the first Cambrian carbonates of the Appalachian section in Labrador (Rowland and Gangloff 1988; F. Debrenne, written comm. 1988). Because the Caborca pole is the only biostratigraphically constrained result in this interval of time, and because it is consistent with other geological evidence, we use it here to constrain the position of North America.

Although a literal interpretation of the Middle and Late Cambrian paleomagnetic data shown in Figure 12.3 imply the presence of a hairpin loop in the Cambrian APW path for North America, this interpretation is also in dispute (Gillett 1982). Nevertheless, an equatorial position with the Cordilleran margin more or less to the north is reasonably consistent with the paleomagnetic data, whether or not this loop exists. 


\subsubsection{Africa}

Perrin et al. (1988) have compiled an extensive list of published paleomagnetic pole positions for the Proterozoic and Cambrian of Africa which includes more than 50 entries. The majority of these, however, have such extraordinarily poor age constraints that it is difficult to place them in either the Proterozoic or Paleozoic, and Perrin et al. (1988) did not attempt to draw an APW path through them. For our reconstruction, however, it is necessary to make some selection of the data which is reasonably consistent with known geological and tectonic events. Figure 12.4 shows our best pick of these points for Vendian and Cambrian time. The N1 pole of Kröner et al. (1980), from the glaciogenic sediments of the Nama Group in Namibia, is perhaps the most reliable direction for the basal Vendian glaciation, and there is reasonable support from similar results from the Nosib Group (McWilliams and Kröner 1981).

The position of the Precambrian-Cambrian boundary on the African APW path has long been a mystery, principally because stratigraphic correlatives of the Tommotian fauna of small shelly fossils had not been located. Recent stratigraphic work in the Anti-Atlas Mountains of Morocco may have resolved this problem, however. A 3-km-thick sequence of Eocambrian shallow water carbonates is present in this area composed, in upward stratigraphic sequence, of the Calcaire Inferieur; the Série Lie de Vin; the Calcaire Supérieur; and the Série SchistoCalcaire. Trilobites and archaeocyathids marking the Atdabanian Stage equivalents first appear in the middle horizons of the Calcaire Supérieur (Debrenne and Debrenne 1978; Sdzuy 1978), which led to the original suggestion that the PrecambrianCambrian boundary lies near the top of the Série Lie de Vin. The late Brian Daily of the University of Adelaide, South Australia, however, claimed to have found tommotids near the base of the Série Lie de Vin (pers. comm. 1979), implying that horizons equivalent to the base of the Tommotian Stage of Siberia would lie somewhere in the uppermost Calcaire Inferieur. A comparison of the carbonate $\delta^{13} \mathrm{C}$ pattern from Morocco of Tucker (1986) and with that from Siberia by Magaritz et al. (1986) and Magartiz (1989) is compatible with this interpretation, and suggests that the large isotopic excursion at the boundary level in Siberia correlates with a similar event about $100 \mathrm{~m}$ below the top of the Dolomie Inferieur of Morocco. Reddish carbonates within the Série Lie de Vin have been interpreted as forming in sabhka environments at the top of shallowing-upward cycles (Latham and Riding, in prep.), and preserve an extremely stable, two-polarity characteristic magnetization (Kirschvink 1980). More recent paleomagnetic work on these sediments reveals a polarity pattern similar to that of the Tommotian of Siberia after the inversion described above (Kirschvink, in prep.), arguing that the pole derived from this formation was acquired early after deposition. As shown in Figure 12.4, we use this pole as our best estimate for the basal Cambrian of Africa.

The subsequent Cambrian APW track for Africa is still poorly determined. However, basement cooling ages along the eastern African margin and in southern India imply that the assembly of the eastern and western halves of Gondwana was complete by ca. $550 \mathrm{Ma}$ (Kröner 1980; and pers. comm. 1988), and it is therefore possible to use this tectonic constraint along with the more reliable Australian paleomagnetic data to constrain the path. The Nama overprint direction (N3 of Kröner et al. 1980) is in the correct vicinity as implied by these constraints (Fig. 12.4), and thus may have been acquired as a result of this final suturing event.

\subsubsection{E Baltic Platform and Fennoscandia}

There are virtually no reliable, biostratigraphically dated paleomagnetic directions for the Baltic Platform from the base of the Vendian through to the Cambrian-Ordovician boundary, and this continent therefore poses more problems in interpreting its tectonic history than any other fragment (e.g., Pesonen et al. 1989). However, there are strong similarities between the Grenville-age basement in North America and Fennoscandia, so an initial placement of the Baltic Platform off the Appalachian margin of North America is reasonable. We have used the analysis of Gower and Owen (1984), which correlates the Sveconorwegian Orogenic Belt in southern Sweden with features surrounding the trans-Labrador batholith, to constrain the Precambrian position of the Baltic Platform relative to North America.

\subsubsection{Tectonic Reconstructions}

Figure 12.5 and Table 12.1 show the basic tectonic reconstructions and associated Euler poles used for producing the maps of Figures 12.6 through 12.11. On Figure 12.5, the continents and fragments are labeled using a two-letter code (AF, AU, etc.) which is translated in the caption for Table 12.1. Further details regarding these reconstructions for some of the major continental fragments are given below.

\subsubsection{A Gondwana}

Several fundamentally different reconstructions for the paleocontinent of Gondwana have been proposed over the past 50 years (e.g., Du Toit 1937; Smith and Hallam 1970; Tarling 1972; Barron et al. 1978; Morgan 1981; Powell et al. 1980). Of these, there is usually a good consensus concerning which continental fragments belong in the separate assembles of the eastern and western portions, but sometimes a wide variance in how the eastern and western areas are reassembled and welded together finally. The western portion usually includes South America and the Falkland Plateau (Malvenas Platform), Africa and the Somolian and Arabian microplates, and the Florida basement, while the eastern area includes Australia, Antarctica, India, and Madagascar. These different reconstructions fall into two basic groups: those which fit Madagascar to Africa adjacent to Kenya (e.g., Du Toit 1937; Smith and Hallam 1970; Powell et al. 1980), and those which place it further south, offshore of Mozambique (Tarling 1972; Barron et al. 1978; Morgan 1981). Initial paleomagnetic evidence for the northerly position (McElhinny and Embleton 1976a) has been subsequently verified by the study of the marine magnetic lineations of the Indian Ocean (Powell et al. 1980), and versions of either the Smith and Hallam (1970) or Powell et al. (1980) reconstructions have been used commonly in paleomagnetic studies ever since (e.g., Embleton et al. 1980).

The basic reconstruction of Gondwana used in all of the 


\section{Plate Identity Map}



Figure 12.5. Tectonic plates used in these reconstructions. Two-letter abbreviations are as given in Table 12.1.

\section{Cryogenian / Vendian Glaciations}

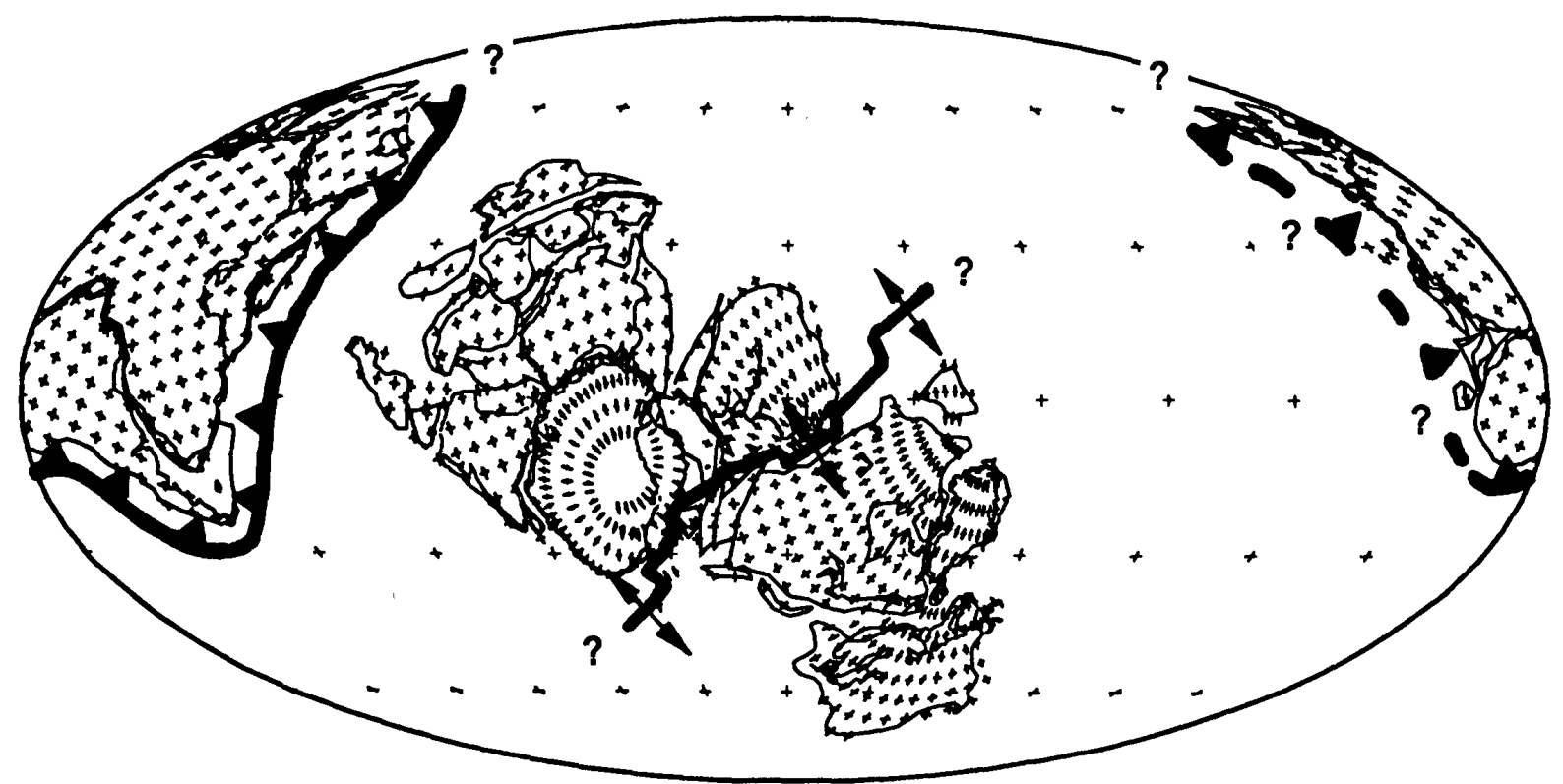

Figure 12.6. A cartoon for a possible basal Vendian glacial reconstruction and associated tectonic boundaries. In Figures 12.6 through 12.11 , the possible locations of trenches are shown by the heavy black lines with tick marks on the upper plate; possible spreading centers are shown by heavy lines with divergent arrows; and possible locations for transform faults are given by heavy lines with opposing arrows. Note the extensive continental areas present in low latitudes implied by this reconstruction. 


\section{Mid-Vendian}

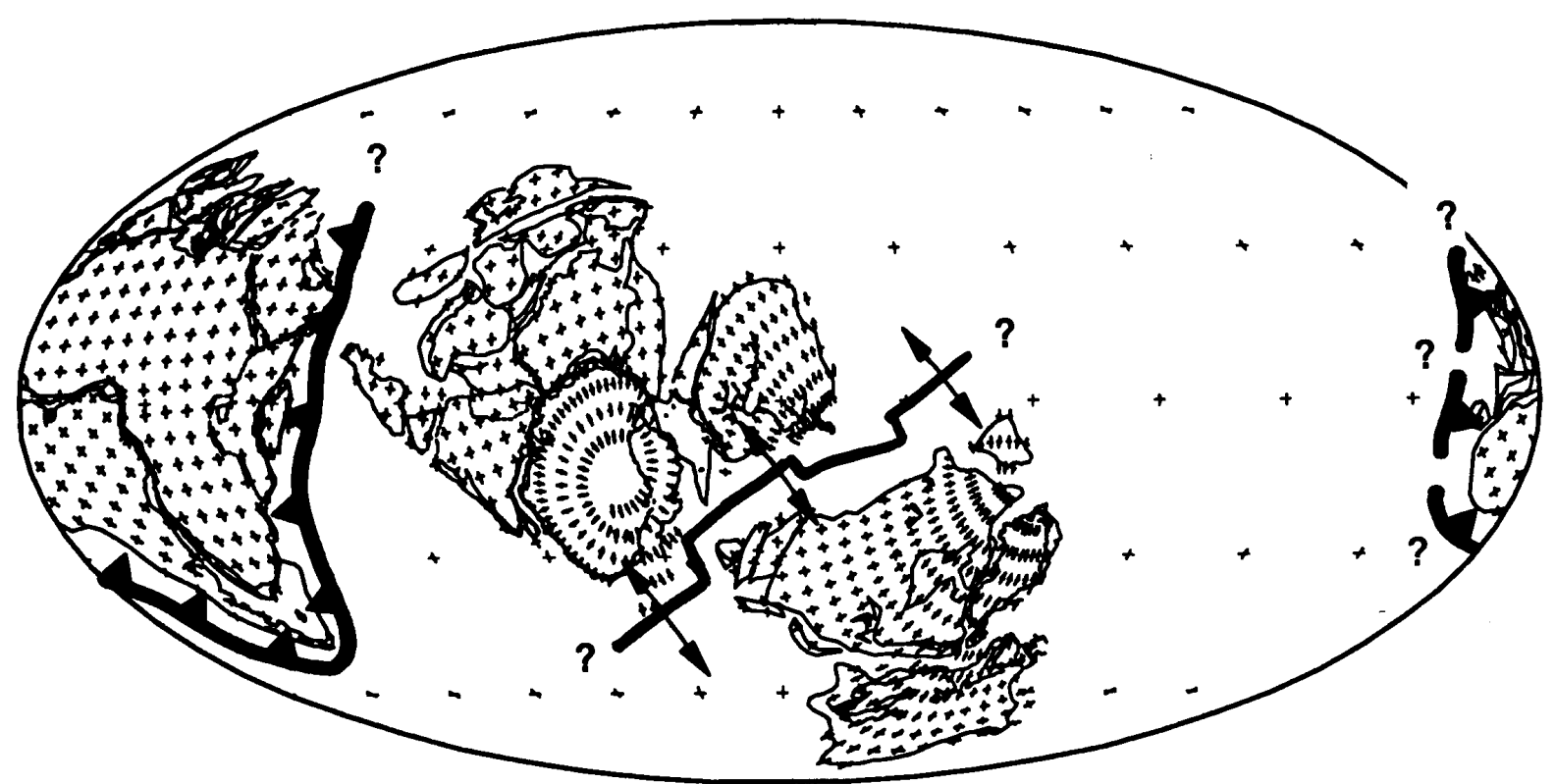

Figure 12.7. Mid-Vendian reconstruction and tectonic boundaries.

\section{Precambrian / Cambrian Boundary}

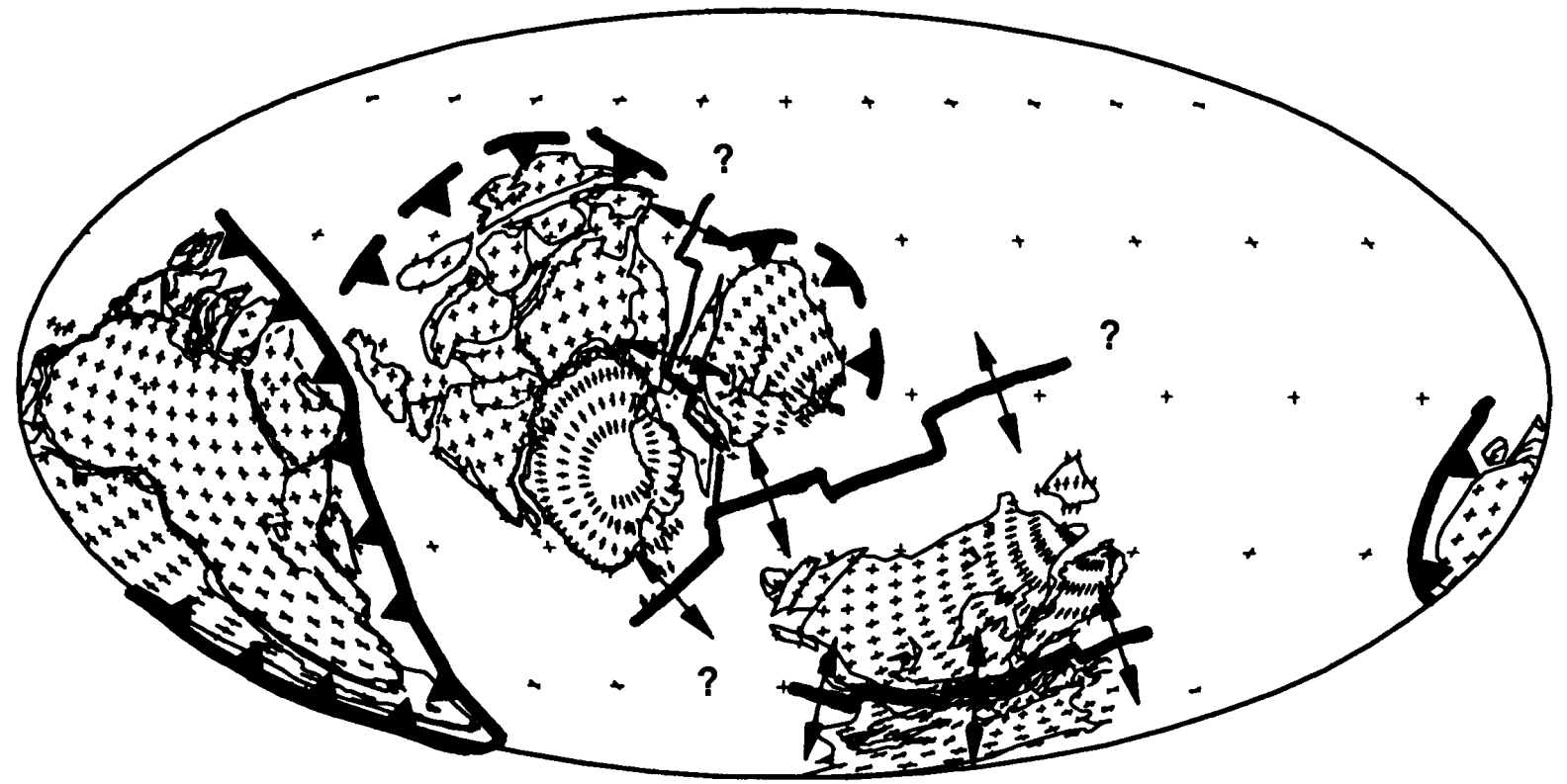

Figure 12.8. Precambrian-Cambrian boundary reconstruction and tectonic boundaries. 
Early / Middle Cambrian Boundary

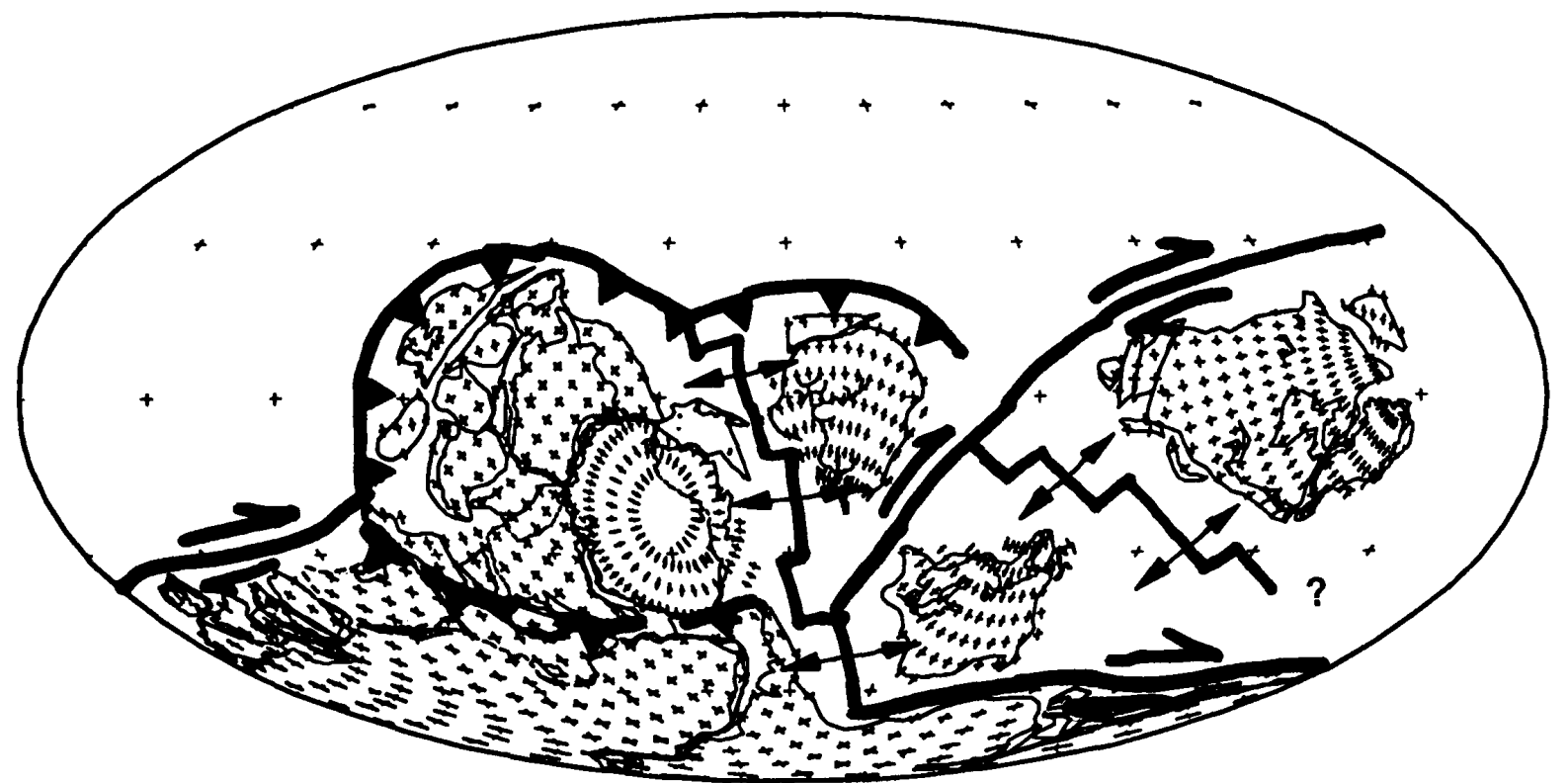

Figure 12.9. Early-Middle Cambrian boundary reconstruction and tectonic boundaries.

Middle / Upper Cambrian Boundary

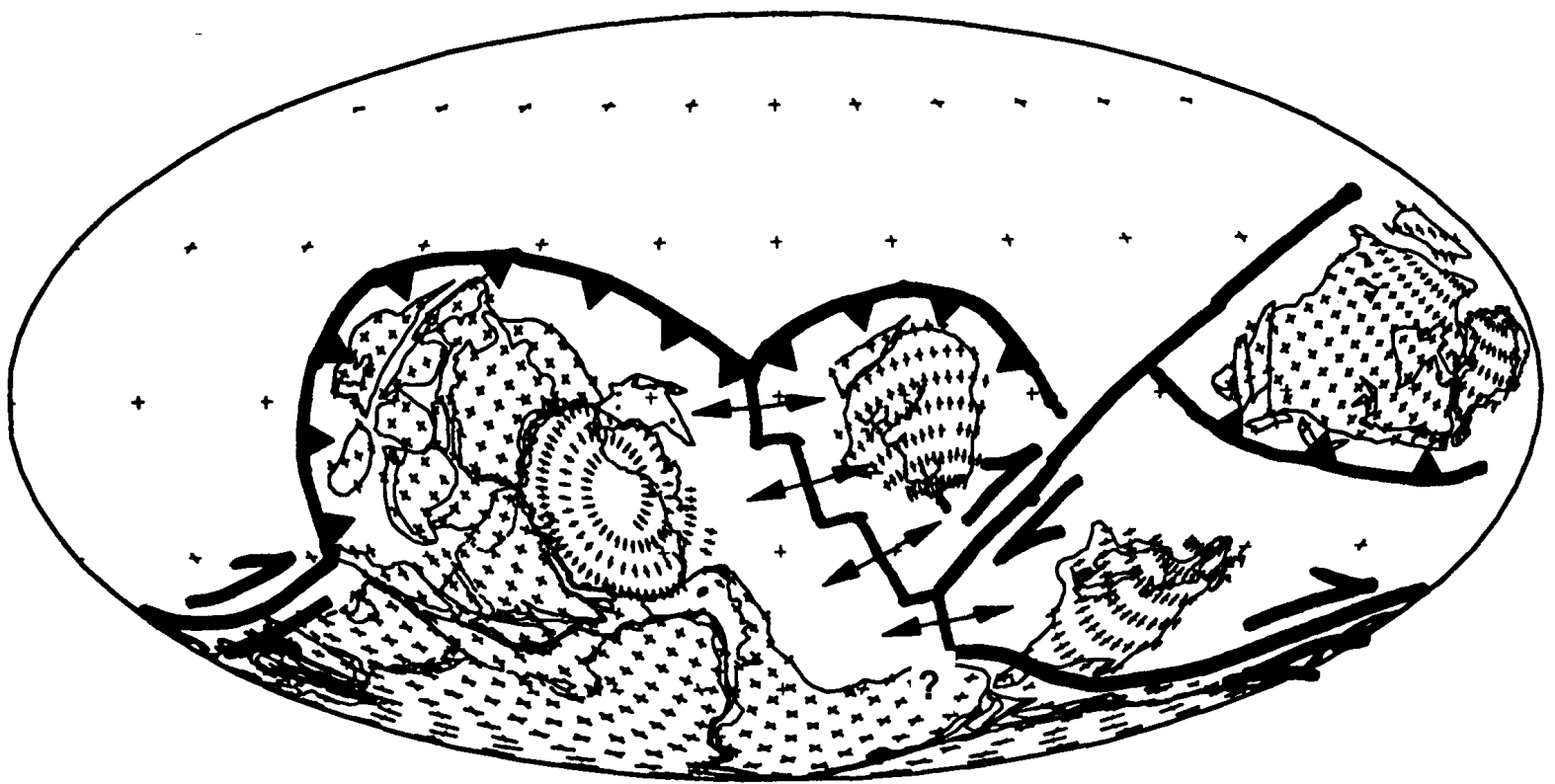

Figure 12.10. Middle-Late Cambrian boundary reconstruction and tectonic boundaries. 


\section{Cambrian / Ordovician Boundary}

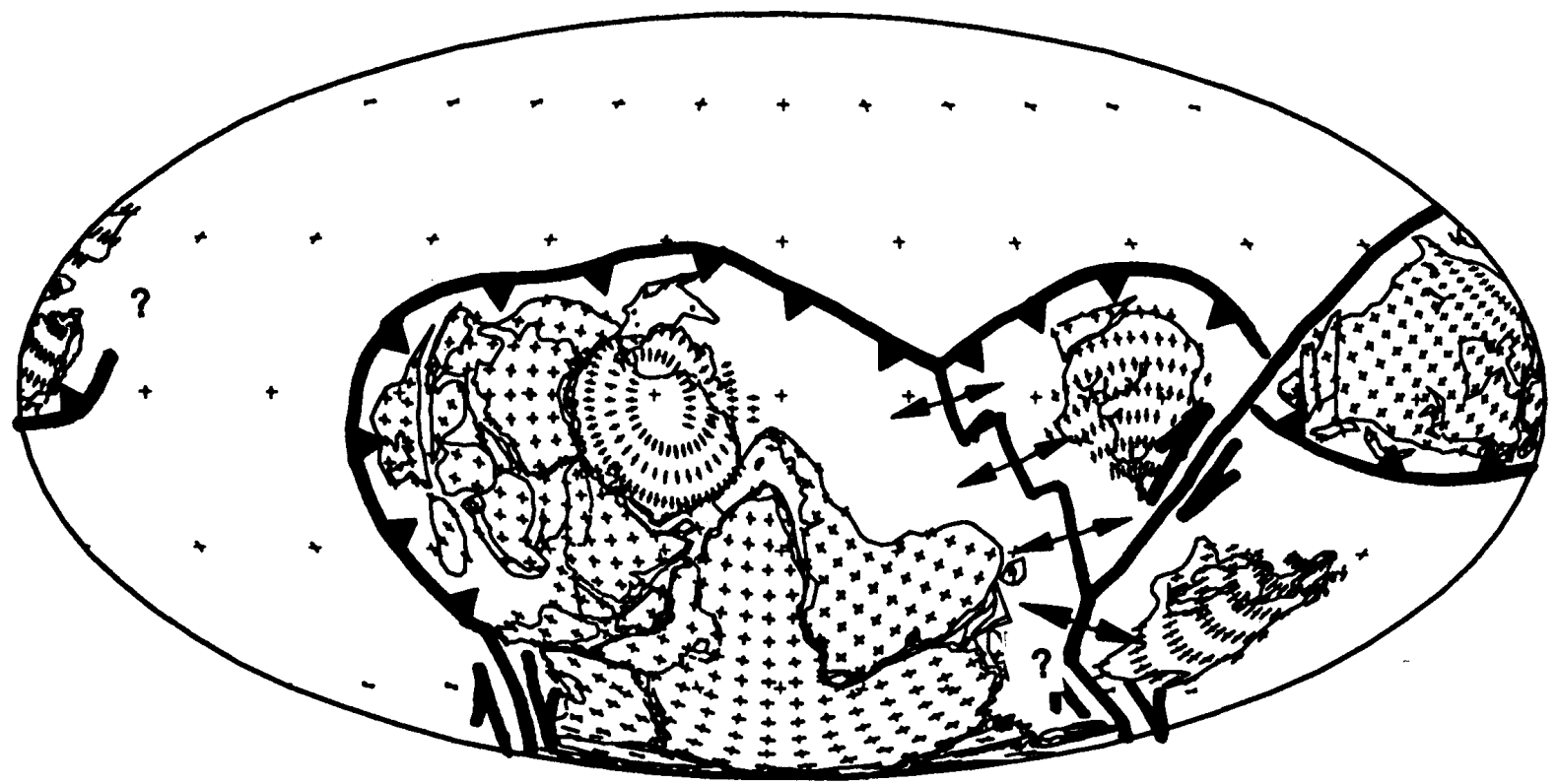

Figure 12.11. Cambrian-Ordovician boundary reconstruction and tectonic boundaries.

Table 12.1. Absolute and relative Euler poles for the reconstructions for Vendian and Cambrian time. Euler poles give the right-handed $(C C W)$ motion of the first plate relative to the second. $A U=$ Australia; $A N=E$. Antarctica; WA $=W$. Antarctica; $S I=S o u t h I$ sland N.Z. + Campbell Plateau; $I N=I$ India $I R=I r a n ; T I=$ Tibet; $T M=$ Tarim $N C=N$. China; $S C=S$. China + Indochina + Burma; $K A=$ Kazakhstan $; A F=$ Africa $; A=S$. America $; A=$ Madagascar $; A R=$ Arabia $; S M=$ Somalia $; C P=C$ Carpathians; $P D=$ Piedmont Terrane; $T U=$ Turkey; $F L=$ Florida; NS = Nova Scotia; $A V=$ Avalon Platform; $I B=I b e r i a ; F R=$ Central Europe; IT $=$ Italy; $S D=$ Sardinia $; Y=$ Yukitan; $G B=S$. Great Britain; $N A=$ North America; $M E=$ Central America; $M Y=$ Northern Sonora Mexico; $G R=$ Greenland $; L=$ Scotland $K O=$ Kolyma $; B O=$ Bolivia; $S J=$ San Juan Argentina; $B P=B a l t i c$ Platform; $S P=$ Siberian Platform. We have obviously erred on the side of including too many microplates, and we specify Euler poles to two decimal places only to minimize cumulative errors for derived poles. Furthermore, the placement of many smaller terranes (such as the Avalon Platform) relative to larger continents, such as Africa and North America, is often poorly constrained. Euler poles given here for these reconstructions are not intended to be definitive; we present them here merely for completeness. Use them at your own risk! Relative longitudes are also unconstrained, except for time intervals in the Cambrian where an attempt is made to keep faunal provinces intact, but separated from each other

\begin{tabular}{llrrrl}
\hline \hline Plate & Age & pLat. & pLong. & Angle & Reference \\
\hline AU & E/O Bdry & 43.74 & -157.04 & 155.93 & Klootwijk 1980 \\
AU & M/L Camb & 58.78 & -168.90 & 154.18 & Klootwijk 1980 \\
AU & E/M Camb & 63.51 & -167.40 & 166.56 & Klootwijk 1980 \\
AU & PE/E Bdry & 67.40 & 157.67 & 179.99 & Kirschvink 1978 \\
AU & Cryo/Vend & 67.40 & 157.67 & 179.99 & Embleton and Williams 1986 \\
AN-AU & Fit & -1.58 & 39.02 & 31.29 & Lawver and Scotese 1987 \\
WA-AN & Fit & 62.27 & 21.84 & 13.27 & Lawver and Scotese 1987 \\
NI-AU & Fit & 24.19 & -19.91 & 44.61 & Lawver and Scotese 1987 \\
SI-WA & Fit & 65.14 & -52.00 & 62.38 & Lawver and Scotese 1987 \\
IN-AN & Fit & 5.93 & -158.43 & 94.53 & Mod. from Morgan 1980 \\
IR-IN & Fit & -31.37 & -98.72 & 15.16 & This paper \\
TI-AU & Fit & 12.52 & -149.61 & 64.20 & This paper \\
TM-AU & Fit & 21.42 & 111.17 & 164.81 & This paper \\
NC-AU & Fit & 22.27 & 120.53 & 179.33 & This paper \\
SC-AU & Fit & 5.76 & 111.02 & 162.82 & This paper \\
KA-AU & Fit & 11.46 & -139.76 & 58.42 & This paper \\
AF & E/O Bdry & 26.71 & -171.38 & 171.31 & Derived from AU path \\
AF & M/L Camb & 41.41 & -179.24 & 177.57 & Derived from AU path \\
AF & E/M Camb & -45.47 & 4.85 & 170.56 & Kröner and McWilliams 1980 \\
AF & PE/E Bdry & -76.73 & 44.50 & 160.52 & Kirschvink 1980 \\
AF & Cryo/Vend & -75.95 & -114.00 & 170.30 & Kröner and McWilliams 1980
\end{tabular}


Table 12.1. (Continued)

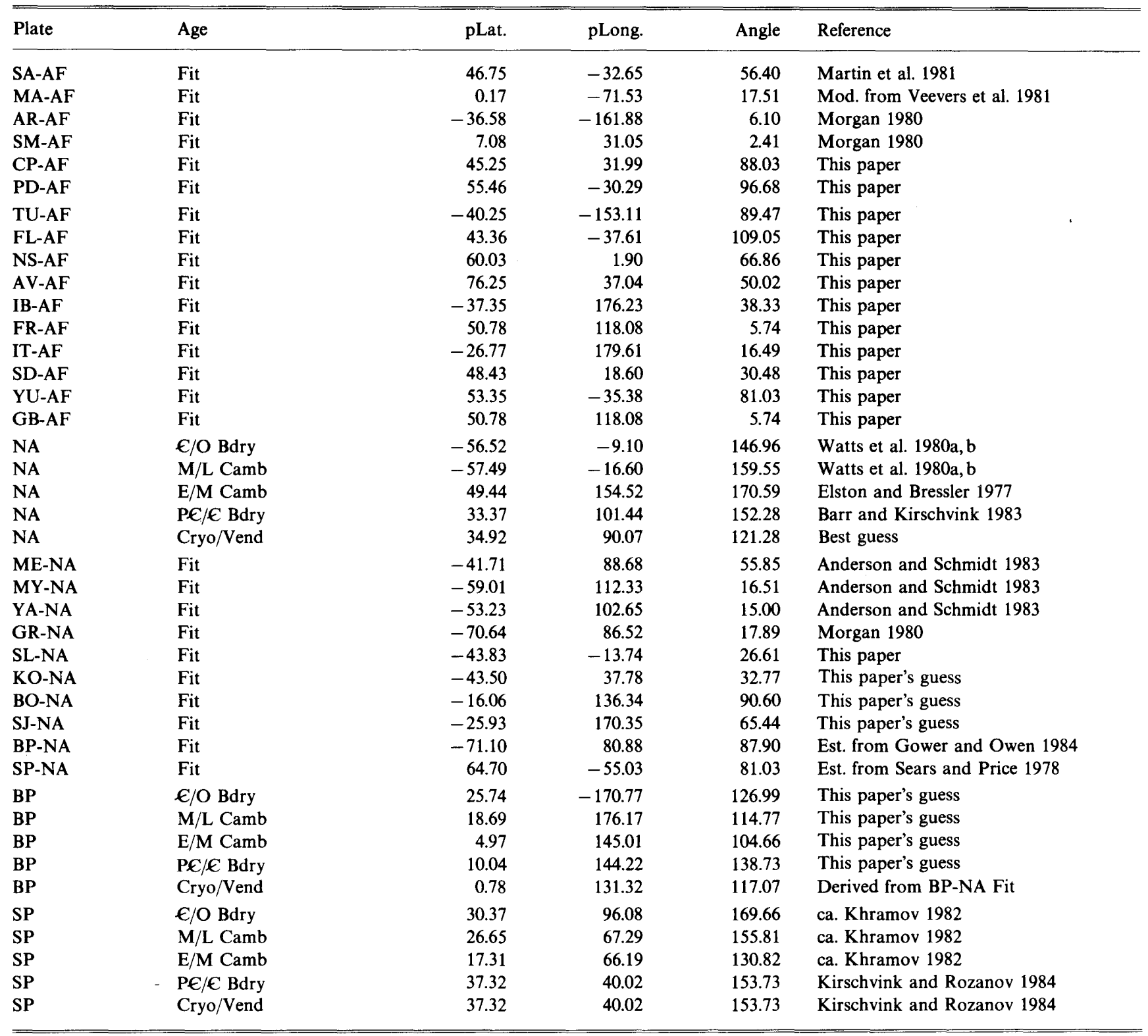

base maps here presented incorporates features from several of these reconstructions. Most important are the Powell et al. arguments that the Falkland Plateau and the Mozambique Ridge are both shallow areas of thin continental crust; hence, the basement rocks of Antarctica are separated by several hundred $\mathrm{km}$ from those of the African mainland (unlike the Smith and Hallam reconstruction). Next, we use the Powell et al. placement of Madagascar against the northern margin of the west Indian shelf; this placement increases the area within the northern margin of Gondwana for use in reconstructing many of the Asian displaced terranes (discussed below). Third, several of the reconstructions assume that the island of Ceylon (Sri Lanka) has moved relative to the tip of India, yet we can find little geologic or paleomagnetic evidence to support this. W. J. Morgan's (1981) fit of India to Antarctica avoids this problem and is compatible with the fracture zone and magnetic anomaly patterns in the Indian Ocean (Powell et al. 1988).
The reconstructions (Figures 12.5 through 12.11) therefore use the basic Morgan (1981) fit of India to Antarctica, and the Powell et al. (1980) placement of Madagascar to India, to link the eastern and western halves of Gondwana, subsequent to their Early or Middle Cambrian suturing at the end of the PanAfrican orogenic event. We have made minor adjustments in the fit of Madagascar against Africa, and India against Antarctica, so as to fit the Falkland Platform against the shelf of Antarctica (Euler poles for this are given in Table 12.1).

A third major chunk of this continent, here called "Northern Gondwana," presumably includes the scattered bits and pieces of Asia, such as Indochina, Burma, the Yangtzee Platform of South China, North China, Tarim, and slivers of Tibet. Although paleontological and lithological similarities in the early Paleozoic generally suggest that these fragments fit together somehow along the lithologically "broken" margins of western Australia, India, and northeastern Africa, the relative 
placement of the pieces has been hampered by inadequate paleomagnetic data and incomplete lithologic and biogeographic analyses. Data from both paleontological and paleomagnetic studies now seem to resolve the bulk of this problem. First, Burrett and Stait (1986) have recognized close similarities between the Cambrian and Ordovician faunas of Burma and the northwest margin of Australia, and argue that Burma should be positioned adjacent to the Canning Basin of Australia. They also note that the South China (Yangtzee) Platform also has similarities with Tibet; and, more recently, Apollonov et al. (1988; and pers. comm. 1988) notes a similar correspondence between Kazakhstan and South China. Several paleomagnetic attempts have also been made during the past ten years to resolve this question by constructing separate APW paths for each of these blocks (e.g., Lin and Fuller 1985; McElhinny et al. 1981), but large gaps in the mid-Paleozoic APW path still leave the hemisphere for the fragments unconstrained. However, this problem has been solved recently by comparing the magnetic polarity pattern across a small time interval around the Cambrian-Ordovician boundary on four continents (Ripperdan and Kirschvink 1989a, b; Ripperdan et al. in review). Results from North America reveal a distinctive normal polarity magnetochron during the Cordyolotus proavis conodont zone. A similar pattern with respect to the conodont zones is also present in North China, Kazakhstan, and South China, and hence the comparison uniquely removes the polarity ambiguity for the APW paths. The Cambrian-Ordovician paleolatitude and biogeographic constraints for these three blocks position them with the relative orientations shown on the reconstructions and in Table 12.1, and produce a remarkable convergence of the Early Cambrian pole positions between North China (Lin et al. 1985), South China (Wu et al. 1989), and Australia (Kirschvink 1978b).

A group of other minor continental fragments with PanAfrican affinities also needs to be repositioned along the northwestern margin of Africa. These include terranes of the Appalachian margin of North America including Florida, the Piedmont, Nova Scotia, and the Avalon zone of Newfoundland (Opdyke et al. 1987; Venkatakrishnan and Culver 1988; O'Brien et al. 1983). We place the American Plate (including southern Great Britain, south-central Europe, and Iberia) adjacent to the northern African margin following the analyses of Perroud et al. (1984), Van der Voo (1988), and Scotese (1984).

\subsubsection{Configuration and Breakup of Late Proterozoic Super(?) Continents}

\subsubsection{A The Vendian World}

Figure 12.6 shows our best guess at the early Vendian configuration of the Late Proterozoic continents, based partially on the paleomagnetic and lithologic constraints outlined above. To summarize, this reconstruction differs in several major respects from previously published reconstructions for the Late Proterozoic (e.g., Morel and Irving 1978; Piper 1986; Donovan 1987; and Bond et al. 1984). First, East and West Gondwana were probably separate entities until sometime in the Early or Middle Cambrian, based largely on the decreasing discrepancy in their relative orientations inferred from their basal Vendian glacial and basal Cambrian pole positions. This interpretation is also supported by the long APW path of Africa during this interval, as well as by the formation of extensive areas of new continental crust in Africa, particularly along the eastern margin (Bertrand and Caby 1978; Kröner 1980; Dixon and Golombek 1988; Venkatakrishnar and Culver 1988). Second, the Australasian fragments of Gondwana are reassembled on the western margin of Australia, greatly reducing the number of separately wandering fragments in the puzzle. Third, we fit Siberia adjacent to Australia and the basement of the Campbell Plateau, oriented according to the Tommotian pole from the Lena River. We assume that it, like Australia, had no motion during Vendian time, and use this fit principally to maintain its proximity to eastern Australia and Antarctica in the Early Cambrian (Palmer and Gatehouse 1972). Fourth, we fit the Baltic Platform to the Appalachian margin of North America following the analysis of Gower and Owen (1984) discussed above. The breakup between the Baltic Platform and Laurentia probably occurred near the end of the Vendian or in the Early Cambrian, based on an upper age constraint of $554 \mathrm{Ma}$ for the rift-related Tibbit Hill Volcanics in Quebec and Vermont (Kumarapeli et al. 1989). Finally, the position of North America (Laurentia) is more problematic. For lack of better constraints, we fit the Cordilleran margin of North America adjacent to the northeast margin of Siberia, as was suggested by Sears and Price (1978) and used extensively in the reconstructions of Piper $(1983,1986)$. This is reasonably consistent with the lithologic and paleomagnetic constraints, although the timing of the rifting on the Cordilleran margin is not well constrained. In the tectonic model, however, it is necessary for Laurentia to move in a southerly direction during the late Vendian to accomodate the Caborca (and perhaps the Sept-Iles) paleomagnetic results. It is possible that this motion was initiated by a Late Proterozoic rifting event along the Cordilleran margin and some other craton (e.g., Armin and Mayer 1983; Bond et al. 1984), and from our previous analysis, Siberia, almost by default, happens to be in the correct orientation for this missing rift partner.

\subsubsection{B Cambrian Events}

It appears that two major plate motions began approximately at the Precambrian-Cambrian boundary and continued until Middle Cambrian time. Paleomagnetic and lithologic evidence suggest that Laurentia reversed its southerly motion and returned to the equator by late Early Cambrian time (based on the Tapeats Sandstone pole of Elston and Bressler 1977), whereas Baltica does not reenter the carbonate belt until Early Ordovician time; this implies a Laurentia-Baltic rifting event involving the Appalachian margin. The consequent formation of the Iapetus Ocean may thus have been responsible for initiating the Cambrian sea-level transgression. Second, sometime in the Early Cambrian, Australia rotated nearly $45^{\circ} \mathrm{CCW}$ around an Euler pole located near Tasmania. We interpret this as happening more or less contemporaneously with the suturing event between the fragments of East and West Gondwana, resulting in the movement of northwest Africa into higher southerly latitudes and out of the carbonate belt (signaled by the transition from the Calcaire Supérieur to the 
Série Schisto-Calcaire in the Anti-Atlas mountains of Morocco). Courjault-Radé $(1987,1988)$ also infers similar motion during Cambrian time for southern Europe, which was probably part of the northwest African promontory. The abrupt cessation of subduction may also be responsible for the extensive shallow epicontinental platforms along the eastern margin of Africa, such as the Faulkland Plateau.

During the Middle Cambrian and first half of the Late Cambrian, the CCW rotation of Australia was temporarily reduced (Klootwijk 1980). This time probably marks the onset of an east-dipping subduction zone and an island-arc along the Australasian margin of Gondwana (including Kazakhstan and perhaps North China). Presumably, the Siberian, Laurentian, and Baltic Plates would have been located due west of this convergent margin, and subduction may have helped all three plates to move eastward. Although this model implies leftlateral oblique subduction between Baltica and Laurentia in the early Paleozoic, there is no good constraint on the amount of separation between them, other than that the faunal provinces are distinct. It is not clear whether they could be as close as suggested by Mason (1988), however, because the deep-water trilobites of Siberia are similar to the shallow Baltic forms, yet both are distinct from those of North America (Jell 1974; Shergold 1988). Unfortunately, the APW paths for all three of these continents are constrained too poorly to resolve even the latitudinal issue at this time (e.g., Van der Voo 1988).
The interval from the mid-Late Cambrian to the CambrianOrdovician boundary contains another $45^{\circ} \mathrm{CCW}$ rotation of Gondwana in what may be a rather short period of time. Interestingly, the APW path for Laurentia is also consistent with roughly $45^{\circ}$ of rotation during essentially the same time period, but in a $\mathrm{CW}$ sense rather than $\mathrm{CCW}$ (Watts et al. $1980 \mathrm{a}, \mathrm{b})$. Because the Gondwanan and Laurentian faunal provinces are quite distinct, the geography is such in this reconstruction that the two Euler poles for these rotations are nearly antipolar, and there is virtually no relative motion between these continents. Hence, true polar wander, which is a displacement between the earth's mantle and core resulting from the realignment of the principal moment of inertial axes of the earth, is a possible explanation for the synchrony and apparent rapidity of this shift. Thermal warming and absorption of a subducting slab stranded by the suture of East and West Gondwana, along with initiation of new subduction zones along the eastern margin of Australia and Antarctica, could provide such a switch in the earth's moment of inertia tensor.

\section{Acknowlegments}

Supported by the PPRG and NSF grants EAR-8721391 and PYI-8351370, and contributions from the Chevron Oil Field Research Company and the Arco Foundation. Contribution no. 4807 of the Division of Geological and Planetary Sciences of the California Institute of Technology. 